\title{
Suppression of Thioacetamide-Induced Hepatic Injury in Rats treatment with Resveratrol: Role of mammalian Target of Rapamycin (mTOR) Cell Signaling
}

\author{
Supresión de la Lesión Hepática Inducida por Tioacetamida en ratas tratadas con Resveratrol: \\ Rol de la vía de Señalización mTOR (mammalian Target of Rapamycin)
}

\author{
Mohammad Dallak ${ }^{1}$; Fahaid Al-Hashem ${ }^{1}$; Mohamed A. Haidara ${ }^{1,2}$; Mohamed Abd Ellatif ${ }^{3,4}$; Samaa S. Kamar ${ }^{5}$; \\ Asmaa M. ShamsEldeeen ${ }^{2}$; Amal F. Dawood ${ }^{6,2}$; Hasnaa A. Ebrahim $^{6,7}$ \& Bahjat Al-Ani ${ }^{1}$
}

DALLAK, M.; AL-HASHEM, F.; HAIDARA, M. A.; ELLATIF, M. A.; KAMAR, S. S.; SHAMSELDEEN, A. M.; DAWOOD, A. F.; EBRAHIM, H. A. \& AL-ANI, B. Suppression of thioacetamide-induced hepatic injury in rats by resveratrol: role of mammalian target of rapamycin (mtor) cell signaling. Int. J. Morphol., 38(3):558-564, 2020.

SUMMARY: Chronic hepatotoxicity is a debilitating and frequently life-threatening disease resulting in progressive liver failure. The toxic chemical, thioacetamide (TAA) is used to evaluate hepatoprotective agents, and the polyphenolic compound, resveratrol was proposed as a novel treatment for diseases with hyperactivation of the mammalian target of rapamycin (mTOR) cell signaling pathway. This analysis sought to investigate the potential protective effect of resveratrol against liver injury induced by TAA via the inhibition of hepatic mTOR. Model group rats received several injections of TAA ( $200 \mathrm{mg} / \mathrm{kg}$; twice a week for 8 weeks) before being sacrificed at week 10 and the protective group was pretreated with resveratrol $(20 \mathrm{mg} / \mathrm{kg})$ daily for two weeks prior to TAA injections and continued receiving both agents until the end of the experiment. Harvested liver tissues were examined using light microscopy and liver homogenates were assayed for biomarkers of inflammation and assessed the levels of mTOR protein in all animal groups. In addition, blood samples were assayed for biomarkers of liver injury enzyme. TAA substantially damaged the hepatic tissue of the model group such as infiltration of inflammatory cells, vacuolated cytoplasm, dark pyknotic nuclei, and dilated congested blood vessel that were effectively protected by resveratrol. Resveratrol also significantly $(\mathrm{p}<0.05)$ inhibited TAA-induced mTOR, high sensitivity c-reactive protein $(\mathrm{hs}-\mathrm{CRP})$, tumor necrosis factor-alpha (TNF- $\alpha$ ), interleukin-6 (IL-6), alanine aminotransferase (ALT) and aspartate aminotransferase (AST) in harvested liver homogenates and blood samples. Thus, we conclude that resveratrol effectively protects against TAA-induced hepatotoxicity in rats, possibly due to the inhibition of mTOR and inflammation.

KEY WORDS: Liver injury; Thioacetamide; mTOR; Resveratrol; Inflammation; Rat model.

\section{INTRODUCTION}

Chronic liver disease represents a significant challenge to the health sector since it can lead to liver failure as well as the high cost of liver transplantation (Neff et al., 2011). The adverse effects of certain chemicals used in industries such as carbon tetrachloride $\left(\mathrm{CCl}_{4}\right)$ and thioacetamide (TAA) on the human body are well documented (Mochizuki et al., 2009). TAA is a severe hepatotoxic agent that causes liver fibrosis (Kadir et al., 2011), cirrhosis and liver cancer (De Minicis et al., 2013), which depends on the length of exposure of the body to this agent. For example, a single injection of TAA caused acute liver injury in rats in the form of tissue necrosis and severe leukocytes infiltration between $6-60$ hours following TAA injections; whereas, biomarkers of tissue necrosis, iNOS and $\mathrm{NF}-\mathrm{kB}$ assessed in liver tissue peaked at one hour post TAA injection (Chen et al., 2008). Inflammation and necrosis of liver tissue also observed after one week following a single injection of TAA (Luo et al., 2015). On the other hand,

\footnotetext{
${ }^{1}$ Department of Physiology, College of Medicine, King Khalid University, Abha 61421, Saudi Arabia.

${ }^{2}$ Department of Physiology, Kasr Al-Aini Faculty of Medicine, Cairo University, Cairo, Egypt.

${ }^{3}$ Department of Clinical Biochemistry, College of Medicine, King Khalid University, Abha 61421, Saudi Arabia.

${ }^{4}$ Department of Medical Biochemistry, College of Medicine, Mansoura University, Mansoura, Egypt.

${ }^{5}$ Department of Medical Histology, Kasr Al-Aini Faculty of Medicine, Cairo University, Cairo, Egypt.

${ }^{6}$ Department of Basic Medical Sciences, College of Medicine, Princess Nourah Bint Abdulrahman University, Riyadh, Saudi Arabia.

${ }^{7}$ Department of Anatomy, College of Medicine, Mansoura University, Mansoura, Egypt.

FUNDING. This work was supported by the Research Deanship of King Khalid University, Abha, Saudi Arabia; Grant number KKU-Project No. R.G.P1./100/40.
} 
DALLAK, M.; AL-HASHEM, F.; HAIDARA, M. A.; ELLATIF, M. A.; KAMAR, S. S.; SHAMSELDEEN, A. M.; DAWOOD, A. F.; EBRAHIM, H. A. \& AL-ANI, B. Suppression of thioacetamide-induced hepatic injury in rats by resveratrol: role of mammalian target of rapamycin (mtor) cell signaling. Int. J. Morphol., 38(3):558-564, 2020.

chronic liver injury model induced by TAA injections twice a week for 6 to 10 weeks caused liver fibrosis and cirrhosis (Wallace et al., 2015; Al-Hashem et al., 2019).

The quiescent, nonproliferative hepatic stellate cells (HSCs) become highly proliferative upon exposing to insults causing these cells producing most of the extracellular matrix $(\mathrm{ECM})$ in the fibrotic liver via the upregulation of mTOR (Neef et al., 2006; Shan et al., 2016). Activated mTOR leads to many downstream cell signalling pathways including the activation of hypoxic transcription factor, HIF- $1 \alpha$, which participates in promoting liver fibrosis (Zhao et al., 2014) and cancer (Masoud \& Li, 2015). The hepatotoxic agents, TAA and CCl4 are reported to activate the mTOR-HIF- $1 \alpha$ axis in many animal models of liver diseases and HSCs cell lines (Zhao et al.; Wu et al., 2016). Furthermore, these agents are also known to augment profibrogenic and inflammatory biomarkers such as $\alpha$-SMA that upregulates fibroblast activity leading to the production of collagen and other fibers (Nouchi et al., 1991; Zhao et al.; Wu et al.), and TNF- $\alpha$ (Morio et al., 2001). Induction of TNF- $\alpha$ and IL-6 caused MMP/TIMP imbalance and collagen production (promoting fibrosis) by HSCs (Robert et al., 2016).

Resveratrol is a polyphenolic anti-inflammatory and antioxidant compound found in grapes, berries, and peanuts (Cudmore et al., 2012). It ameliorates several types of liver diseases such as hepatic sinusoidal obstruction, hepatic steatosis (Trepiana et al., 2018), and inhibits HSCs (Kawada et al., 1998). Resveratrol was proposed as a novel treatment for diseases with mTOR pathway hyperactivation such as cancers and tumor syndromes (Alayev et al., 2016). We recently reported that the antidiabetic, anti-inflammatory, and antioxidant drug, metformin, is able to inhibit TAAinduced hepatotoxicity associated with the inhibition of mTOR hyperactivation and inflammation (Al-Hashem et al.). Therefore, we speculated that activation of the mTOR and inflammation by TAA in a rat model of liver injury could be inhibited by resveratrol.

\section{MATERIAL AND METHOD}

Animals. Albino male rats weighing 180-200 gm were used for the experiments with the approval of Ethical Committee of the college of medicine, King Khalid University, Abha, Saudi Arabia. The animals were obtained from the animal house of the College of Medicine of King Khalid University where they fed with standard rat's pellets and allowed free access to water. They were housed at a controlled ambient temperature of $25 \pm 2{ }^{\circ} \mathrm{C}$ and $50 \pm 10 \%$ relative humidity, with 12-h light/12-h dark cycles. Experiments were performed according to the Guide for the Care and Use of Laboratory Animals published by the US National Institutes of Health (NIH publication No. 85-23, revised 1996).

Experimental design. After a one week adaptation period, rats were randomly allocated into 4 groups $(n=6)$ as follows: Control group (Control): non- treated rats that were injected intraperitoneally (i.p.) with vehicle; resveratrol group (RES): rats treated with resveratrol $(20 \mathrm{mg} / \mathrm{kg}$ ) daily for 10 weeks; TAA-treated group, the model group (TAA): rats were injected i.p. with $200 \mathrm{mg} / \mathrm{kg}$ TAA, 2 x per week for 8 weeks (week 3 -week 10); the protective group (RES+TAA): rats were treated with resveratrol from week 1 - week 10 and injected with TAA from week 3 - week 10.

Histological Analysis. Liver specimens were immediately fixed in $10 \%$ formal saline for 24 hours. Paraffin blocks were prepared,and $5 \mathrm{~mm}$ thick sections were subjected to hematoxylin and eosin $(\mathrm{H} \& \mathrm{E})$ stain to elucidate the status of hepatic architecture and the structural changes.

Western Blotting Analysis of mTOR. Proteins were extracted from liver tissues, and $20 \mu \mathrm{g}$ of protein per sample were immunoblotted as we described previously (Al-Ani et al., 2010). Membranes were probed with anti-mTOR-phosphoS2448 (Thermo Fisher Scientific, MA, USA) at 40C overnight. Proteins were visualized using the ECL detection kit (Amersham-Pharmacia, UK). Relative expression was determined using Image analysis software to read the band intensity of the target proteins against the control sample after normalization by $\alpha$-actin on the Chemi Doc MP imager.

\begin{abstract}
Alanine Aminotransferase (ALT), Aspartate Aminotransferase (AST), High Sensitive C-reactive protein (CRP), Tumor Necrosis Factor Alpha (TNF- $\alpha$, and Interleukin-6 (IL-6) Enzyme-Linked Immunosorbent Assay (ELISA). Serum levels of ALT and AST were measured using an enzymatic kit (Randox Laboratories, UK) according to the manufacturer's instructions. ELISA kits were purchase to determine serum levels of high sensitive C-reactive protein (hsCRP, Cat. No. ERC1021-1) from ASSAYPRO, USA. ELISA kits for determination of liver tissue homogenate levels of Interleukin-6 (IL-6, Cat No. ELR0IL6-001), and tumour necrosis factor alpha (TNF- $\alpha$, Cat No. R63635), were used according to the manufacturer's instructions.
\end{abstract}

Statistical analysis. The data was expressed as mean \pm standard deviation (SD). Data was processed and analyzed using the SPSS version 10.0 (SPSS, Inc., Chicago, Ill., USA). Oneway ANOVA was done followed by Tukey's post hoc test. Pearson correlation statistical analysis was done for detection of a probable significance between two different parameters. Results were considered significant if $\mathrm{p} \leq 0.05$. 
DALLAK, M.; AL-HASHEM, F.; HAIDARA, M. A.; ELLATIF, M. A.; KAMAR, S. S.; SHAMSELDEEN, A. M.; DAWOOD, A. F.; EBRAHIM, H. A. \& AL-ANI, B. Suppression of thioacetamide-induced hepatic injury in rats by resveratrol: role of mammalian target of rapamycin (mtor) cell signaling. Int. J. Morphol., 38(3):558-564, 2020.

\section{RESULTS}

Induction of chronic liver injury in rats by TAA. We first sough to characterize the rat model of chronic liver injury induced by the heapatotoxic agent, TAA. Injection of the model group of rats with TAA $(200 \mathrm{mg} / \mathrm{kg}$ body weight, i.p.) twice a week for 8 weeks caused a sharp increase in biomarkers of liver injury and abnormal liver tissue architecture (Fig. 1). High blood levels of ALT (Fig. 1A) and hs-CRP (Fig. 1B), and H\&E images of liver section (Figs. $1 \mathrm{C}$ and $1 \mathrm{D})$ confirmed liver injury and abnormal changes to the liver parenchyma in the model group (TAA). H\&Estained liver section from the model group (Fig. 1D) displays ballooning degeneration of hepatocytes, vacuolated cytoplasm, dark pyknotic nuclei, induced the presence of numerous inflammatory cell infiltration and dilated congested blood vessel. However, another H\&E image at similar magnification prepared from liver sections of the control rats (Fig. 1C) shows unremarkable liver architecture.

Resveratrol inhibits TAA-induced liver injury enzymes and inflammatory biomarkers. We measured the tissue levels of the inflammatory biomarkers, CRP, TNF- $\alpha$ and IL- 6 in all animal groups at week 10. TAA augmented blood levels of CRP and liver tissue homogenates levels of TNF- $\alpha$ and IL-6, and resveratrol treatment (RES+TAA) significantly $(\mathrm{p}<0.05)$ inhibited these biomarkers (Table I). However, the inhibition by resveratrol was still significant $(\mathrm{p}<0.05)$ when compared with the control groups. This means, a partial inhibition by resveratrol was achieved.

To determine whether resveratrol pre-treatment can reduce the release of the liver injury enzymes ALT and AST in rats injected with TAA, one group of rats was given resveratrol daily prior (for 2 weeks) and post (for 8 weeks) TAA injections. Compared to the control groups, TAA caused a three-fold increase in both ALT and AST that was significantly $(\mathrm{p}<0.05)$ inhibited by resveratrol (RES+TAA) (Table I). However, the levels of ALT and AST in the RES +TAA group were still significant $(\mathrm{p}<0.05)$ to the control group, which means, a partial inhibition by resveratrol was demonstrated.

Resveratrol inhibits TAA-induced hepatic mTOR activity in rats. Resveratrol was proposed as a novel treatment for diseases with mTOR pathway hyperactivation such as cancers and tumor syndromes (Alayev et al.). To test the hypothesis that resveratrol pretreatment can inhibit TAAinduced mTOR liver cell signaling, we assessed the levels of mTOR protein in all animal groups (Fig. 2). TAA strongly augmented mTOR protein levels, which was effectively inhibited by resveratrol (Figs. 2A and 2B). However, the degree of inhibition of $\mathrm{mTOR}$ by resveratrol was still significant $(\mathrm{p}<0.05)$ to the control rats (Fig. 2B).
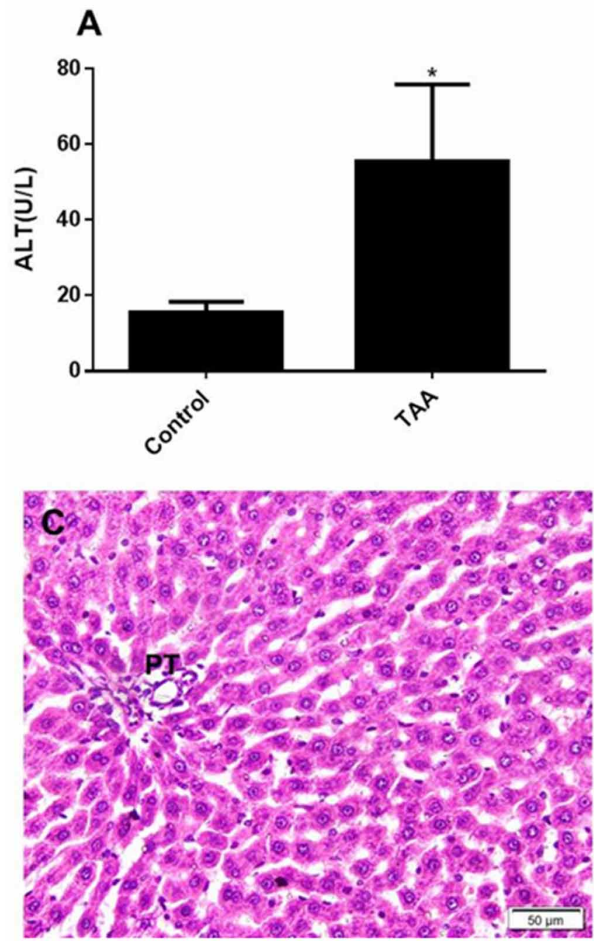

560
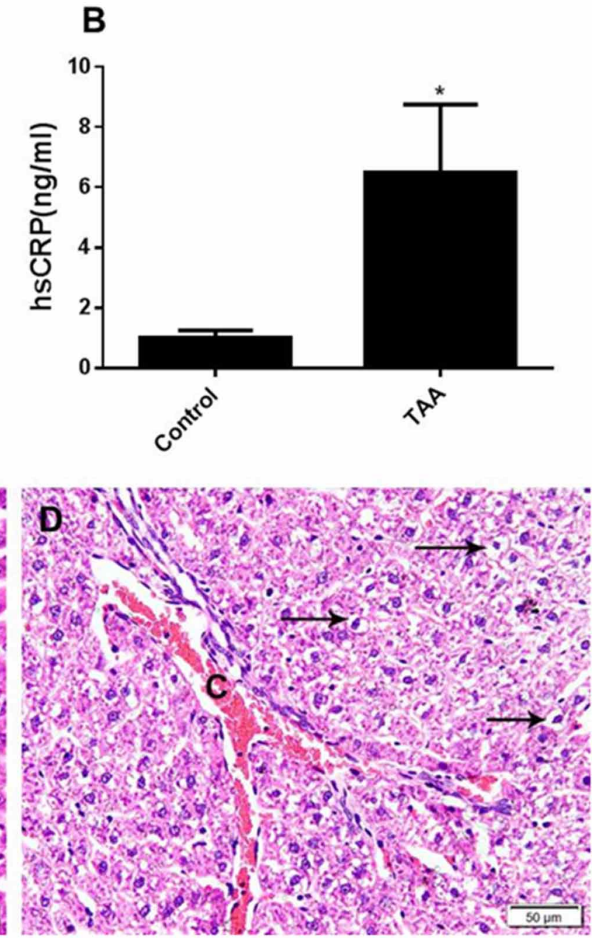

Fig. 1. Induction of chronic liver injury in rats by TAA. Blood levels of ALT (A) and hs-CRP (B) were measured after 10 weeks in the model group (TAA) compared to the control group rats ( $n=6$ for each group). Results represent the mean $( \pm \mathrm{SD})$, and experiments were performed in triplicate. ${ }^{*} \mathrm{p}<0.05$ versus control. (C and D). H\&E stained images (x400) of harvested tissues obtained after 10 weeks from the liver of model group (D) compared to control group (C) rats are visualized using light microscopy. Note that arrows point to vacuolated cytoplasm and dark pyknotic nuclei. Abbreviations: PT, portal tract; C, dilated congested blood vessel; TAA: thioacetamide. 
DALLAK, M.; AL-HASHEM, F.; HAIDARA, M. A.; ELLATIF, M. A.; KAMAR, S. S.; SHAMSELDEEN, A. M.; DAWOOD, A. F.; EBRAHIM, H. A. \& AL-ANI, B. Suppression of thioacetamide-induced hepatic injury in rats by resveratrol: role of mammalian target of rapamycin (mtor) cell signaling. Int. J. Morphol., 38(3):558-564, 2020.

Table I. Effects of resveratrol on blood and liver homogenates levels of C-reactive protein (CRP), tumor necrosis factor-alpha (TNF- $\alpha$ ), interleukin-6 (IL-6), alanine transaminase (ALT), and aspartate transaminase (AST) in all experimental groups of rats.

\begin{tabular}{llllll}
\hline $\begin{array}{l}\text { Animal } \\
\text { groups }\end{array}$ & $\begin{array}{l}\text { CRP } \\
(\mathrm{ng} / \mathrm{ml})\end{array}$ & $\begin{array}{l}\text { TNF- } \alpha \\
(\mathrm{pg} / \mathrm{gm})\end{array}$ & $\begin{array}{l}\text { IL-6 } \\
(\mathrm{pg} / \mathrm{gm})\end{array}$ & ALT (U/L) & AST \\
\hline Control & $1.00 \pm 0.29$ & $18.18 \pm 3.015$ & $21.60 \pm 3.81$ & $15.50 \pm 2.81$ & $16.67 \pm 5.89$ \\
RES & $0.801 \pm 0.18$ & $19.02 \pm 3.15$ & $23.52 \pm 3.6$ & $17.33 \pm 2.42$ & $15.50 \pm 4.41$ \\
TAA & $6.31 \pm 2.39 \mathrm{a}$ & $111.7 \pm 14.0 \mathrm{a}$ & $131.1 \pm 3.75 \mathrm{a}$ & $55.38 \pm 20.37 \mathrm{a}$ & $58.50 \pm 11.93 \mathrm{a}$ \\
RES+TAA & $3.27 \pm 1.32 \mathrm{ab}$ & $80.47 \pm 19.82 \mathrm{ab}$ & $72.60 \pm 19.67 \mathrm{ab}$ & $28.29 \pm 7.43 \mathrm{ab}$ & $33.71 \pm 6.31 \mathrm{ab}$
\end{tabular}

Values are expressed as Mean \pm SD for 6 rats in each group. Values were considered significantly different at $P<0.05$. a: Significant in comparison to control; b:Significant in comparison to TAA. TAA: thioacetamide; RES: resveratrol.

A

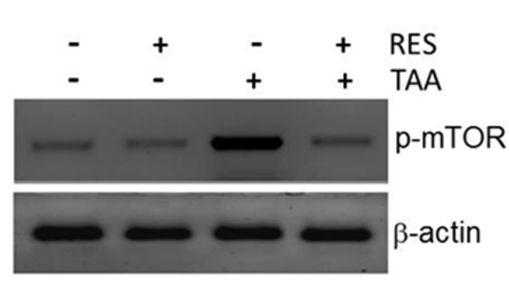

C

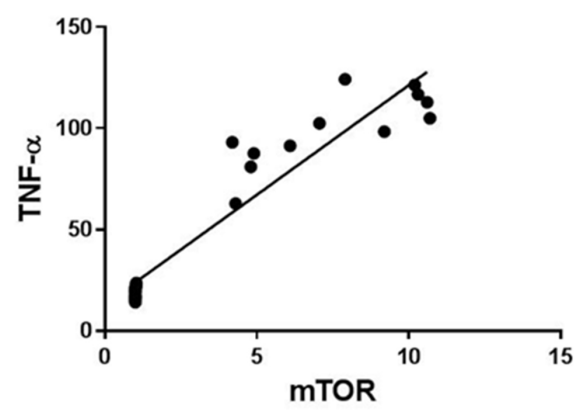

B

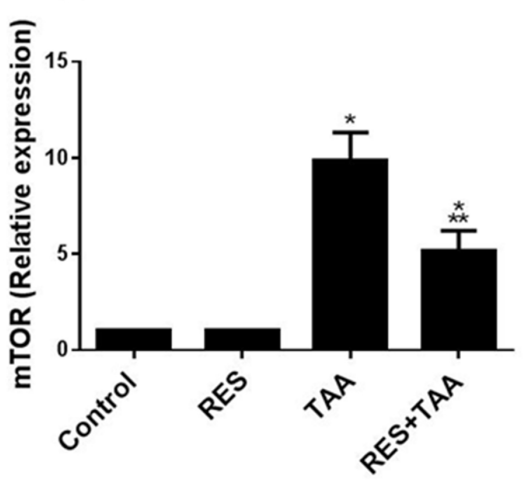

D

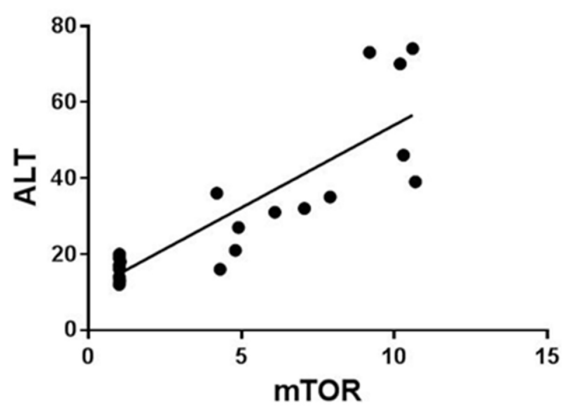

Fig. 2. Resveratrol reduces TAAinduced $\mathrm{mTOR}$ signaling protein. Liver tissue lysates prepared from all the groups of rats were examined by Western blotting for phospho-mTOR (p-mTOR) (A and $\mathrm{B})$, and $\alpha$-actin as a loading control (A). Histograms represent the relative expression of this signaling protein are shown (B). (C and D). Positive correlation between mTOR and TNF- $\alpha(\mathrm{C})$ and mTOR and ALT (D). ALT: alanine aminotransferase; mTOR: mammalian target of rapamycin; TNF- $\alpha$ : tumor necrosis factor- $\alpha$; TAA: thioacetamide.
We further determined the correlation between mTOR scorning and the tissue levels of inflammation, and serum levels of liver injury biomarkers in order to confirm and characterize that the role of the resveratrol is stable and an appropriate agent in liver injury in rats, and to further support the link between mTOR and inflammation, and serum levels of liver injury enzymes. As shown in Figs. 2C and 2D, a positive correlation was shown between mTOR and these biomarkers; mTOR versus TNF- $\alpha(r=0.9476)(p<0.0001)$, and mTOR versus ALT $(r=0.8628)(\mathrm{p}<0.0001)$.

Resveratrol protects hepatic tissue against TAAinduced liver injuries. We tested the hypothesis that resveratrol can protect liver tissue against damage induced by TAA in rats. Harvested liver tissues obtained from all animal groups after 10 weeks on resveratrol and 8 weeks on TAA were stained with hematoxylin and eosin $(\mathrm{H} \& \mathrm{E})$ and then examined under light microscopy (Fig. 3). Representative H\&E stained sections of liver from the model group showed that TAA substantially distorted the liver parenchyma with ballooning degeneration of hepatocytes, vacuolated cytoplasm, dark pyknotic nuclei, induced the presence of numerous inflammatory cell infiltration and dilated congested blood vessel (Fig. 3B). Whereas, a normal tissue structure in the control group displaying cords of hepatocytes with acidophilic cytoplasm and vesicular nuclei surrounding portal tract (Fig. 3A). Resveratrol treatment preserved liver architecture against damage induced by TAA (Figs. 3C and 3D). However, small foci of inflammatory cell were noted in some fields. 
DALLAK, M.; AL-HASHEM, F.; HAIDARA, M. A.; ELLATIF, M. A.; KAMAR, S. S.; SHAMSELDEEN, A. M.; DAWOOD, A. F.; EBRAHIM, H. A. \& AL-ANI, B. Suppression of thioacetamide-induced hepatic injury in rats by resveratrol: role of mammalian target of rapamycin (mtor) cell signaling. Int. J. Morphol., 38(3):558-564, 2020.
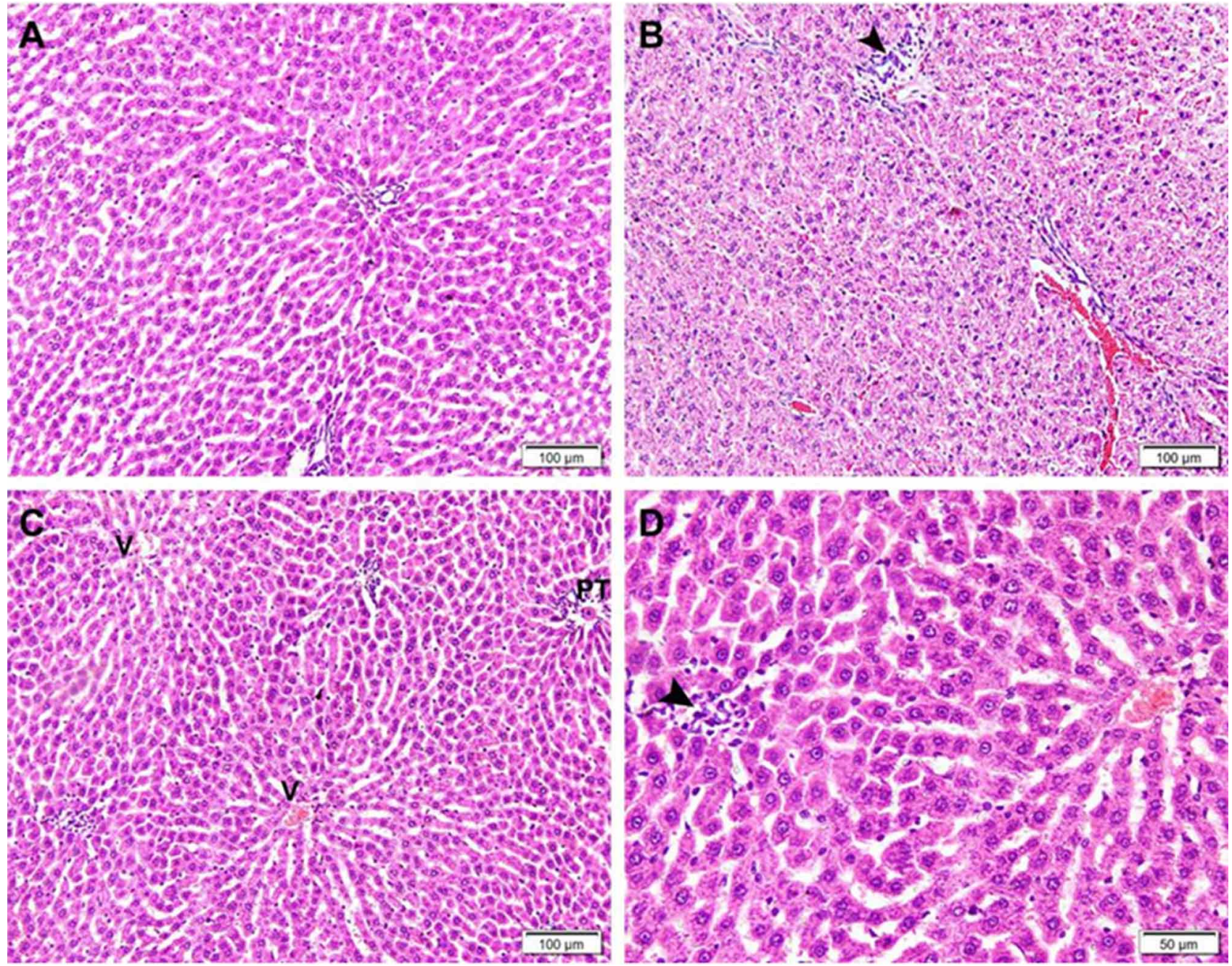

Fig. 3. Resveratrol protects liver architecture against injury induced by TAA. H\&E stained images (A,B,C, x100; D, x400) of harvested tissues obtained after 10 weeks from the liver of the control group (A), TAA group (B), and the protective group, RES+TAA (C and D). Note that arrowheads in (B and D) point to the inflammatory cell infiltration. Abbreviations: PT, portal tract; V, central vein. TAA: thioacetamide.

\section{DISCUSSION}

In this study, we investigated whether the polyphenolic compound resveratrol can protect the liver from the hepatotoxic agent TAA in a chronic liver injury animal model. Therefore, we induced liver injury in rats using TAA in the presence and absence of resveratrol. Here, we report that resveratrol protected liver parenchyma against damage induced by TAA (Fig. 3), and inhibited biomarkers of inflammation, liver injury enzymes, and fibrosis (Table I and Fig. 2) in liver tissue homogenates and blood. These conclusions are supported by the ELISA, Western blots, and light microscopy data indicating that TAA induced liver tissue damage, inflammation, and mTOR in rats, which were substantially protected by resveratrol. Our results were thus consistent with our working hypothesis that resveratrol can protect against TAA-induced hepatotoxicity via the inhibition of mTOR hyperactivation and biomarkers of inflammation and liver injury enzyme in rats.

Elevated levels of mTOR in TAA-induced chronic liver injury (Fig. 2) together with other previously published work (Wu et al.) that showed TAA caused liver fibrosis and increased levels of mTOR in mice and hepatic stellate cells, further strengthens the link between TAA and liver fibrosis and mTOR cell signaling. Indeed, mTOR was found to increase these profibrogenic biomarkers and hence promote fibrosis (Zhao et al.). In addition, inflammation is well- 
DALLAK, M.; AL-HASHEM, F.; HAIDARA, M. A.; ELLATIF, M. A.; KAMAR, S. S.; SHAMSELDEEN, A. M.; DAWOOD, A. F.; EBRAHIM, H. A. \& AL-ANI, B. Suppression of thioacetamide-induced hepatic injury in rats by resveratrol: role of mammalian target of rapamycin (mtor) cell signaling. Int. J. Morphol., 38(3):558-564, 2020.

known inducers of liver fibrosis, and an association between inflammation and mTOR in animal models of liver fibrosis was documented (Wang et al., 2014), which are in agreement with our findings of elevated levels of mTOR, CRP, TNF$\alpha$, and IL-6 in TAA-induced liver injury.

Resveratrol was proposed as a novel treatment for diseases with mTOR pathway hyperactivation (Alayev et al.), which is in agreement with our data shown in Fig. 2. In addition, previous reports used resveratrol to successfully inhibit liver injuries induced by a chemical insult, $\mathrm{CCl} 4$ in animal models and hepatic cells (Rivera et al., 2008) that is also in agreement with our TAA and resveratrol data (Figs. 2 and 3 and Table I).

In summary, this study demonstrates that TAA induced liver injury, mTOR, and inflammation, which were protected by resveratrol.

DALLAK, M.; AL-HASHEM, F.; HAIDARA, M. A.; ELLATIF, M. A.; KAMAR, S. S.; SHAMSELDEEN, A. M.; DAWOOD, A. F.; EBRAHIM, H. A. \& AL-ANI, B. Supresión de la lesión hepática inducida por tioacetamida en ratas tratadas co resveratrol: Rol de la vía de señalización mTOR (mammalian Target of Rapamycin). Int. J. Morphol., 38 (3):558-564, 2020.

RESUMEN: La hepatotoxicidad crónica es una enfermedad debilitante y potencialmente mortal que produce insuficiencia hepática progresiva. La toxicidad del químico de la tioacetamida (TAA) se utiliza para evaluar los agentes hepatoprotectores y el compuesto polifenólico, resveratrol, se propuso como un nuevo tratamiento para enfermedades con hiperactivación de la vía de señalización celular mTOR (mammalian Target of Rapamycin). Aquí buscamos investigar el posible efecto protector del resveratrol contra la lesión hepática inducida por TAA a través de la inhibición de la vía de señalización mTOR en hepatocitos. Las ratas del grupo modelo recibieron varias inyecciones de TAA $(200 \mathrm{mg} / \mathrm{kg}$; dos veces por semana durante 8 semanas) antes de ser sacrificadas en la semana $10 \mathrm{y}$ el grupo protector se trató previamente con resveratrol $(20 \mathrm{mg} /$ $\mathrm{kg}$ ) diariamente durante dos semanas antes de las inyecciones de TAA y continuó recibiendo ambos agentes hasta el final del experimento. Se examinaron los tejidos hepáticos recolectados usando microscopía óptica y se analizaron los homogeneizados hepáticos para detectar biomarcadores de inflamación y se evaluaron los niveles de proteína mTOR en todos los grupos de animales. Además, se analizaron muestras de sangre para detectar biomarcadores de la enzima de lesión hepática. TAA dañó sustancialmente el tejido hepático del grupo modelo, con infiltración de células inflamatorias, citoplasma vacuolado, núcleos picnóticos oscuros y vasos sanguíneos congestionados dilatados que estaban efectivamente protegidos por el resveratrol. El resveratrol también inhibió significativamente $(\mathrm{p}<0.05)$ mTOR, proteína C-reactiva (hs-CRP), factor de necrosis tumoral alfa (TNF- $\alpha$ ), interleucina- 6 (IL-6), alanina aminotransferasa (ALT ) y aspartato aminotransferasa (AST) en las muestras de sangre y de hígados recolectados. En conclusión, el resveratrol protege eficazmente contra la hepatotoxicidad inducida por TAA en ratas, posiblemente debido a la inhibición de mTOR y de la inflamación.

PALABRAS CLAVE: Lesión hepática; Tioacetamida; mTOR; Resveratrol; Inflamación; Modelo de rata.

\section{REFERENCES}

Al-Ani, B.; Hewett, P. W.; Cudmore, M. J.; Fujisawa, T.; Saifeddine, M.; Williams, H.; Ramma, W.; Sissaoui, S.; Jayaraman, P. S.; Ohba, M.; et al. Activation of proteinase-activated receptor 2 stimulates soluble vascular endothelial growth factor receptor 1 release via epidermal growth factor receptor transactivation in endothelial cells. Hypertension, 55(3):689-97, 2010.

Al-Hashem, F.; Al-Humayed, S.; Amin, S. N.; Kamar, S. S.; Mansy, S. S.; Hassan, S.; Abdel-Salam, L. O.; Ellatif, M. A.; Alfaifi, M.; Haidara, M. A.; et al. Metformin inhibits mTOR-HIF-1a axis and profibrogenic and inflammatory biomarkers in thioacetamide-induced hepatic tissue alterations. J. Cell. Physiol., 234(6):9328-37, 2019.

Alayev, A.; Berger, S. M. \& Holz, M. K. Resveratrol as a novel treatment for diseases with mTOR pathway hyperactivation. Ann. N.Y. Acad. Sci., 1348(1):116-23, 2016.

Chen, T. M.; Subeq, Y. M.; Lee, R. P.; Chiou, T. W. \& Hsu, B. G. Single dose intravenous thioacetamide administration as a model of acute liver damage in rats. Int. J. Exp. Pathol., 89(4):223-31, 2008.

Cudmore, M. J.; Ramma, W.; Cai, M.; Fujisawa, T.; Ahmad, S.; Al-Ani, B. \& Ahmed,A. Resveratrol inhibits the release of soluble fms-like tyrosine kinase (sFlt-1) from human placenta. Am. J. Obstet. Gynecol., 206(3):253.e10-5, 2012.

De Minicis, S.; Kisseleva, T.; Francis, H.; Baroni, G. S.; Benedetti, A.; Brenner, D.; Alvaro, D., Alpini, G. \& Marzioni, M. Liver carcinogenesis: rodent models of hepatocarcinoma and cholangiocarcinoma. Dig. Liver Dis., 45(6):450-9, 2013.

Kadir, F. A.; Othman, F.; Abdulla, M. A.; Hussan, F. \& Hassandarvish, P. Effect of Tinospora crispa on thioacetamide-induced liver cirrhosis in rats. Indian J. Pharmacol., 43(1):64-8, 2011.

Kawada, N.; Seki, S.; Inoue, M. \& Kuroki, T. Effect of antioxidants, resveratrol, quercetin, and n-acetylcysteine, on the functions of cultured rat hepatic stellate cells and Kupffer cells. Hepatology, 27(5):1265-74, 1998.

Luo, M.; Dong, L.; Li, J.; Wang, Y. \& Shang, B. Protective effects of pentoxifylline on acute liver injury induced by thioacetamide in rats. Int. J. Clin. Exp. Pathol., 8(8):8990-6, 2015.

Masoud, G. N. \& Li, W. HIF-1a pathway: role, regulation and intervention for cancer therapy. Acta. Pharm. Sin. B, 5(5):378-89, 2015.

Mochizuki, M.; Shimizu, S.; Urasoko, Y.; Umeshita, K.; Kamata, T.; Kitazawa, T.; Nakamura, D.; Nishihata, Y., Ohishi, T. \& Edamoto, H. carbon tetrachloride-induced hepatotoxicity in pregnant and lactating rats. J. Toxicol. Sci., 34(2):175-81, 2009.

Morio, L. A.; Chiu, H.; Sprowles, K. A.; Zhou, P.; Heck, D. E.; Gordon, M. K. \& Laskin, D. L. Distinct roles of tumor necrosis factor-alpha and nitric oxide in acute liver injury induced by carbon tetrachloride in mice. Toxicol. Appl. Pharmacol., 172(1):44-51, 2001.

Neef, M.; Ledermann, M.; Saegesser, H.; Schneider, V. \& Reichen, J. Lowdose oral rapamycin treatment reduces fibrogenesis, improves liver function, and prolongs survival in rats with established liver cirrhosis. J. Hepatol., 45(6):786-96, 2006.

Neff, G. W.; Duncan, C. W. \& Schiff, E. R. The current economic burden of cirrhosis. Gastroenterol. Hepatol. (N. Y.), 7(10):661-71, 2011.

Nouchi, T.; Tanaka, Y.; Tsukada, T.; Sato, C. \& Marumo, F. Appearance of alpha-smooth-muscle-actin-positive cells in hepatic fibrosis. Liver, 11(2):100-5, 1991. 
DALLAK, M.; AL-HASHEM, F.; HAIDARA, M. A.; ELLATIF, M. A.; KAMAR, S. S.; SHAMSELDEEN, A. M.; DAWOOD, A. F.; EBRAHIM, H. A. \& AL-ANI, B. Suppression of thioacetamide-induced hepatic injury in rats by resveratrol: role of mammalian target of rapamycin (mtor) cell signaling. Int. J. Morphol., 38(3):558-564, 2020.

Rivera, H.; Shibayama, M.; Tsutsumi, V.; Perez-Alvarez, V. \& Muriel, P. Resveratrol and trimethylated resveratrol protect from acute liver damage induced by CCl4 in the rat. J. Appl. Toxicol., 28(2):147-55, 2008.

Robert, S.; Gicquel, T.; Bodin, A.; Lagente, V. \& Boichot, E. Characterization of the MMP/TIMP imbalance and collagen production induced by IL-1b or TNF-a release from human hepatic stellate cells. PLoS One, 11(4):e0153118, 2016

Shan, L.; Ding, Y.; Fu, Y.; Zhou, L.; Dong, X.; Chen, S.; Wu, H.; Nai, W.; Zheng, H.; Xu, W.; et al. mTOR overactivation in mesenchymal cells aggravates CCl 4- induced liver fibrosis. Sci. Rep., 6:36037, 2016.

Trepiana, J.; Milton-Laskibar, I.; Gómez-Zorita, S.; Eseberri, I.; González, M.; Fernández-Quintela, A. \& Portillo, M. P. Involvement of 5'-activated protein kinase (AMPK) in the effects of resveratrol on liver steatosis. Int. J. Mol. Sci., 19(11):220-31, 2018

Wallace, M. C.; Hamesch, K.; Lunova, M.; Kim, Y.; Weiskirchen, R.; Strnad, P. \& Friedman, S. L. Standard operating procedures in experimental liver research: thioacetamide model in mice and rats. Lab. Anim., 49(1 Suppl.):21-9, 2015

Wang, W.; Yan, J.; Wang, H.; Shi, M.; Zhang, M.; Yang, W.; Peng, C. \& Li, H. Rapamycin ameliorates inflammation and fibrosis in the early phase of cirrhotic portal hypertension in rats through inhibition of mTORC1 but not mTORC2. PLoS One, 9(1):e83908, 2014.

Wu, Y. L.; Zhang, Y. J.; Yao, Y. L.; Li, Z. M.; Han, X.; Lian, L. H.; Zhao, Y. Q. \& Nan, J. X. Cucurbitacin E ameliorates hepatic fibrosis in vivo and in vitro through activation of AMPK and blocking mTOR-dependent signaling pathway. Toxicol. Lett., 258:147-58, 2016.

Zhao, Y.; Ma, X.; Wang, J.; Zhu, Y.; Li, R.; Wang, J.; He, X.; Shan, L.; Wang, R.; Wang, L.; et al. Paeoniflorin alleviates liver fibrosis by inhibiting HIF-1a through mTOR-dependent pathway. Fitoterapia, 99:318-27, 2014.
Corresponding author:

Professor Bahjat Al-Ani

Department of Physiology

College of Medicine

King KhalidUniversity

Abha 61421

SAUDI ARABIA

E-mail: bahjat_alani@yahoo.com

Received: 08-08-2019

Accepted: 18-10-2019 